\title{
PROBLEMS AND PROSPECTS OF SOCIAL PROTECTION IN UKRAINE
}

\section{PROBLEMI I PERSPEKTIVE SOCIJALNE ZAŠTITE U UKRAJINI}

\author{
Vita Byndyu \\ "PVNZ" Bukovina University, Chernovtsy, Ukraine
}

\section{() MESTE NGO}

JEL category: I3, I31, I38

\begin{abstract}
In the current economic conditions, any person may be in a situation of social disadvantage as a result of unemployment or obtaining temporary or total disability (illness, accident, old age, disability, child care, etc.). That is why the government acting guarantee social rights of the population should provide effective social policies to build effective social protection system that would provide support to citizens upon the occurrence of various social risks and contribute to the well-being of people. Unfortunately, social protection in Ukraine currently has a lot of problems caused by the instability of the political situation and economic relations in society, increase inflation, rising unemployment, economic crisis, major sectors of the economy.
\end{abstract}

This article reveals the essence of the concepts of social protection and social security. It gives the analysis of the main aspects of social protection in Ukraine, defines challenges of social insurance in the insurance market of Ukraine and provides suggestions to improve social policy. Special attention is paid to the description of principles which should be base of the social protection policies in the state and the ways of their improvement to overcome the current crisis. Also here are discussed the conceptual ideas for changing strategic priorities and ideology implementation of social protection in Ukraine, viewing incomes policy, reform of social services.

Keywords: social security, social security, social standards, social insurance, social risks, social policy, welfare.

\section{Apstrakt}

U sadašnjim ekonomskim uslovima, bilo koja osoba može da bude u stanju socijalne hendikepiranosti kao posledica nezaposlenosti ili nastanka privremene ili potpune nesposobnosti ( bolesti, nesreće,

The address of the author:

Vita Byndyu

㫪三”v vitka.dva84@gmail.com starost, invalidnost, čuvanje dece, itd). Zato delovanje vlade $u$ smislu obezbeđivanja socijalnih prava stanovništva treba da obezbedi efikasnu socijalnu politiku u cilju izgradnje efikasnog sistema socijalne zaštite koji će obezbediti podršku građanima 
pri pojavi raznih socijalnih rizika i doprinosa dobrobiti naroda. Nažalost, socijalna zaštita u Ukrajini trenutno ima mnogo problema izazvanih nestabilnošću političke situacije i ekonomskim odnosima u društvu, praćenih povećanjem inflacije, porašću nezaposlenosti, ekonomskom krizom.

Ovaj članak otkriva suštinu koncepta socijalne zaštite i socijalne sigurnosti. To daje analizu glavnih aspekata socijalne zaštite u Ukrajini, definiše izazove socijalnog osiguranja na tržištu osiguranja Ukrajine i daju sugestije za poboljšanje socijalne politike. Posebna pažnja je posvećena opisu principa na kojima bi trebalo da se bazira politika socijalne zaštite u državi i načinima njenog unapređenja da bi se prevazišla trenutna kriza. Takođe, ovde se raspravlja $i$ o konceptualnim idejama za promenu strateških prioriteta i sprovođenje ideologije socijalne zaštite u Ukrajini, imajući u vidu prihode i reformu socijalnih usluga.

Ključne reči: socijalna zaštita, socijalno osiguranje, socijalni standardi, socijalni rizici, socijalna politika, zaštite: socijalna zaštita, socijalno osiguranje, socijalni standardi, socijalni rizici, socijalna politika, zaštite

\section{INTRODUCTION}

In today's complex stage of Ukraine considerable attention needs to be reformed social security system, as it plays a special role in maintaining stability and social equilibrium in society. Today, giving priority to economic growth over the expansion of the social security system can lead to the impoverishment of the people, the deterioration of society, and finally - to economic stagnation. That social protection measures have become an effective mechanism to promote sustainable economic growth thanks to the support of the working population, expanding its capabilities, increase domestic demand and productivity.

During the years of independence, Ukraine's social policy has not emerged as a coherent, integrated strategy; it actually replaced the accumulation of various types of poorly informed and unsupported features of budget financing payments, benefits, subsidies, etc. Economic reforms have led to a global redistribution of wealth and income, and haphazard social event had a noticeable effect and did not significantly impact on poverty in Ukraine. As a result, the number, complexity and urgency of social problems that need solving and active participation of the state increases. Their solution is an absolute must for the modern Ukraine, and they asked Rod, main directions of reforming social policies.

After the independence of Ukraine Institute of Social Security gradually became the leading form of citizens' rights to social services and social security. However, the Institute continues to evolve under the influence of economic factors and demographic, creating a pretty tough external conditions for its operation.

\section{CURRENT ISSUES}

Important component of the social protection system is social insurance. Addressing social insurance in Ukraine is much more difficult and slower compared to developed countries.

In the current economic conditions, any person may be in a situation of social disadvantage as a result of unemployment or obtaining temporary or total disability (illness, accident, old age, child care, etc.). In Ukraine today there is no effective mechanism to protect from the effects of potential social risks (Kochemyrovs"ka \& Pyshhulina, 2012) (especially for families with children, the disabled and those who supervise them, people with disabilities, the unemployed and forced others).

Guaranteeing social protection of the population by two ways, the State:

1. has a redistribution of wealth in the way of funding social programs;

2. gives people the opportunity to provide themselves with a pension, sickness funds, etc., as well as a choice of a social service in the market.

According to the ILO Declaration on Social Justice for a Fair Globalization for the purposes of a core element of economic and social policy of any country is a full and productive employment (Haen, 2008).

On the one hand, this means promoting the widest possible excretion of working (including part of working) population in the open labor market. On the other - it is income from a full and productive employment insurance form and fiscal framework 
of social protection systems to reduce the impact of social risk and return people to the labor market.

In this context, the State assumes the implementation of programs of the labor market; improve people's lives, ensuring the minimum wage, the implementation of social security measures for those who need it. Social security is not so much the mechanism of crisis intervention as a prevention strategy adverse impact of potential social risks. It is thus not only eliminates the effects of social inequality, but also provides a balanced redistribution, becoming way to reduce inequality and poverty (non ) marginalized individuals, families and social groups in a way:

- adherence to the principles of self-sufficiency of economically active population, that is to create conditions so that worker was able to earn as much as allowing its ability and initiative; support themselves and their families; pay taxes, including social security on the other;

- ensuring a guaranteed level and quality of life of those members of society who are unable to achieve its own, thanks to measures of social support for the most vulnerable.

Part 1 of Article 46 of the Constitution of Ukraine states that "citizens have the right to social protection, including the right to security in the event of complete, partial or temporary disability, widowhood, unemployment due to circumstances beyond their control, and in old age and other cases provided by law" (Ukrayiny, 2009), that social protection is not limited to security in the event of a risk.

Thus, policies for social protection should be based on the following principles:

- personal liability of employees, their employers, workers and other categories of able-bodied persons for financial security acceptable level of social protection;

- solidarity support workers and employers to the most vulnerable groups of the population and their families;

- optimal support (principle of subsidiary), which determines the extent (boundaries) of the solidarity support, fixes its size and form of presentation.

Unfortunately, the term "social security" and "social security" does not have an official definition in national legislation; in Ukraine there is also a single law that would regulate all aspects of social security.

The essence of the term "social security" (Shul"ha, 2011 ) is that - a way of redistributing national income in order to ensure a certain standard of living for everyone in the conditions of social risks.

Social security - a system of government measures to provide financial assistance to offset, reduce or prevent the negative impact of social risks to persons who, because of their independent life circumstances do not have sufficient means of subsistence.

"Social security" as a set of social relations between people on the one hand, and state agencies, local governments and organizations about providing citizens with special funds, the budget, health care, pensions, allowances and other types of support in the event of life circumstances, resulting in a loss or reduction in income, increased costs, low income, poverty - the other (Shajhatdinov V. S., 1999).

The purpose of social security is levelling the social situation of vulnerable persons in relation to other members of society. It is a form of expression of policy, aimed at financial support of certain categories of citizens (at the expense of state and local governments, social security funds, extra-budgetary funds for social purposes, other means specified by law) in the event of circumstances that are recognized by the state at this stage of social significant and result in a loss or reduction of income, low income and poverty.

Social Security is in the direct provision of government payments to individuals who are entitled to them, and to ensure the maintenance of social, medical care, free of charge or on concessional services for citizens.

It covers activities that provide assistance in cash or in kind, including in such cases (VI Doklad, 2011):

- lack of (or lack of) income from work (due to illness, disability, maternity, injury at work, unemployment, old age, etc.);

- lack of access to health care or financial inaccessibility of health services; 
- inability or poor ability to maintain a family person, especially a child or disabled (forced idle) family member;

- general poverty and social exclusion.

Social security - a practical activity to create a favorable environment, protection of motherhood and childhood, the implementation of family assistance, public health, public training, employment, health and safety, regulation of wages and incomes, providing citizens with housing, regulating rights of citizens, financial services and ensuring the disabled and others in need of social support (Shajhatdinov V. S., 1996).

Social security - a system of state guarantees for the rights of citizens to work and assistance in case of unemployment; to maintain living standards by revising the minimum basic social security with an increase in prices for consumer goods and services; on state aid, benefits and other social assistance to poor individuals and families with children; to maintenance upon reaching retirement age, and in the case of temporary or permanent loss of health and work opportunities, etc (Honcharenko, 2002).

In a more general sense of social security can be defined as an obligation of society, which implements the state to maintain a specific category of people on special occasions and special means by society (Mel"nyk, 2003, p. 81).

Social security is the implementation of key social policy due to the complex organizational, legal and socio- economic measures aimed at:

- creation for people of working age appropriate conditions for their social, economic and spiritual needs;

- provide a guaranteed level of income is not below the minimum subsistence level citizens in need of social assistance.

The term "social security" includes social rights (to work, education, housing, recreation, safe environment, health, adequate standard of living, safe working conditions, wages not less than the minimum established standards, etc.).

However, the EU has changed the approach to the definition of social security has long defined as a set of measures to protect citizens against social risks and often identified with the term "social security", i.e. with cash outlays. At the European Forum of the EU (Brussels, 1998) was proposed to consider social protection as a livelihood in a broad sense, that is to cover not only social security but also social integration, education, health, housing policy, social services and so on. This is the content laid down in Art. 46 of the Constitution of Ukraine, according to which the concept of "social security" is broader than "social security" (Ustynov, 2011).

Social protection measures set out in Art. 46, although similar to social security, but include, in particular, compensation, restitution, restoration of rights and other social benefits, which can be determined by the rules of law not only social security but also in other areas of law - labor, civil, administrative, financial etc. The term "social security" includes social rights (to work, education, housing, recreation, safe environment, health, adequate standard of living, safe working conditions, wages not less than the minimum established standards, etc.). However, the legal definition of "social security" and "social security" is not a mistake to use these terms interchangeably (Shul"ha, 2011), meaning that they cannot be reduced to a purely financial (monetary) component.

In order to ensure the realization of basic social rights and guarantees of citizens Ukraine acceded to most of the universal human rights treaties recognizes the jurisdiction of the UN Committee on Human Rights and the European Court of Human Rights, which requires the need to bring national legislation in line with international obligations.

However, the implementation of international law in national law and application of the provisions of ratified international legal instruments as directly applicable still a problem.

State selectively and inconsistently came to giving consent to be bound by other international agreements, providing higher standards compared to the fundamental acts of international law. Most international treaties ratified without making corresponding changes to the laws of Ukraine with the adoption of new or repeal existing laws that do not meet international obligations taken.

The state also has a permanent system of monitoring the fulfilment of international legal obligations in the social area. 
Action Plan "Ukraine - EU" (Dokument 994_693, 2005) defines benchmarks for reform, including the introduction of market relations in the system of social services and European standards into national legislation and practice.

It should be noted that the Constitution of Ukraine declared our state social requiring it to regulate economic processes, establish and apply fair and effective forms of social redistribution of income in order to ensure the well-being of all citizens (Dokument v001p710-05, 2005). The Constitution of Ukraine are enshrined social rights and guarantees:

- the right to social security;

- the right to housing;

- the right to an adequate standard of living for themselves and their families;

- the right to health protection, medical care and medical insurance;

- the right of orphans and children deprived of parental care in state detention;

- the right to education.

Since the proclamation of social initiatives passed not so much time in Ukraine has not yet formed a systematic program of reforms to overcome the many problems accumulated over previous years. Among them are:

- high level of poverty, including employed, which is unable to raise their own revenues;

- disadvantage especially for families with children: poverty in families with two children is $39.6 \%$ of the total, with three $-53.8 \%$ with four or more $-72.3 \% 33$;

- increase the vulnerability of large families, families with disabled children and other accommodation and a large proportion of the population in conditions that do not meet basic needs due to inadequate definition of the minimum consumer basket and the structure of a living wage;

- transformation sources provide citizens towards increasing the share of social transfers;

- lack of motivation, social injustice and financial insecurity privileges, causing an increase in their revenues - poor economic growth and inequality;

- inadequacy of social assistance and the need for the introduction of a consolidated system to provide targeted assistance and social services;

- the unreliability of statistical indicators on the number, status, income and consumption level populations with low incomes, which makes it impossible to provide a reasonable estimate of the poverty level and perform predictive calculations necessary budgetary allocations for social needs, especially at the regional level;

- imperfect information base;

- poor information support reform of the social assistance system - the population does not have the necessary information about the objectives and the state guarantees social protection to low-income citizens.

The main role of the social security and welfare state plays in Ukraine, while the Law of Ukraine "On Social Services" has created an opportunity to engage in the provision of social services to non-governmental organizations and institutions; Similar provisions are contained in other regulations applicable social legislation (Shul"ha, 2011).

Social security is in the form of services in residential institutions, financial aid, social benefits and services provided to the community. However, despite the existence of a number of benefits and social services in Ukraine in practice is practically ineffective because the available benefits and assistance is scarce and not able to provide a decent level of living of citizens belonging to vulnerable groups (pensioners, the disabled, large families her and others).

Today in the state there is a situation in which social support, implemented in three main forms (social benefits, social benefits and subsidies) are too complex and opaque. In particular, the main problems of the current system of social support are:

- low coverage of the poor social support. Total $56.8 \%$ of the poor (according to the criterion of the minimum subsistence level) receiving at least one type of social support;

- poor targeting the provision of social support. The distribution of government social transfers is unfair: less than $23 \%$ of the total amount falling to the poor, etc. (almost 17 billion USD annually, or about $6 \%$ of revenues) provided non-poor population; 
- gear housing subsidies and benefits for housing and utilities built on excessive consumption norms of these services, which lead to inefficient use of budget funds.

- The reasons for the above problems are:

- providing the majority of benefits going without income and estate (property) held by the beneficiary. Distorted philosophy of social support: social assistance targeted at maximizing coverage;

- lack of information required for accounting and monitoring of actual consumption of social assistance and income assessment of applicants to receive it;

- lack of social support system of incentives for the efficient use of resources allocated to it, inflated rates of consumption of utility services to the public. For example, in Ukraine is used 108 cubic meters of water per year and per capita, while in Europe there is used 73.

Social Protection and Social Security is currently the largest expenditure item of the consolidated budget of Ukraine. Total funding for it exceeds the total expenditures on health, education and economic activity.

The social protection system in Ukraine requires new approaches to the development and application of standards, and it is one of the strategic directions of social reforms. The role of government is, first, in establishing standards that would ensure the implementation of the strategy improving quality of life. Second priority in optimizing the social security system should be no increase and enhance a variety of benefits and deprivations overcome by creating (restoration) of the social services for all categories of people available regardless of income, place of residence, age, number of children, marital status, ethnic or religious affiliation, etc.

Reforming the mechanism of functioning of social funds is advisable to state on the basis of:

- clearly define the sources and amount of funding for different types of social security;

- centralize and streamline the collection of premiums;

- improvement of control methods and the role of social partners in the management of social insurance;

- maintaining social guarantees;
- creating economic prerequisites of wage growth as the most important factor of social insurance.

Given the shortcomings of the social security system by the Committee on Economic Reforms under the President of Ukraine has developed a program of economic reforms for 2010-2014 "Prosperous Society, Competitive Economy, Effective State", which suggests that to enhance the targeting of all types of social support are necessary the following measures:

- analysis and evaluation of all types of social support;

- unification ( the principles of targeting and incorporation of incomes) approaches to the provision of all social assistance (except assistance at birth or adoption of a child, disabled since childhood and children with disabilities) and subject to income beneficiaries;

- modernization of the housing subsidy program by improving the mechanisms for the provision and implementation of social norms of consumption of utility services;

- the indirect methods for assessing incomes, claiming to receive social support;

- excluding income by providing all kinds of benefits (other than benefits for individuals with exceptional contributions to the country).

The program assumes that ensure effective management of the system of social support achieved as a result (Anon, 2010):

- the creation of a unified database of recipients of all types of social support, a common information environment of Labor and Social Welfare, Pension Fund, the State Tax Service of civil registration;

- the creation of the State Agency of Social Inspectorate under the Ministry of Labor and Social Policy to verify the delivery of social benefits and support vulnerable families with the assistance of other social services (assistance from employment - for social care at home);

- implementation of the monitoring and evaluation of programs of social support on an ongoing basis.

For Economically responsible behavior of recipients of social support should: 
- develop and implement a system economically and socially reasonable standards of consumption of utility, transportation and other services for their subsequent use in determining the amount of social support;

- set production equipment for the account of the actual consumption of services (including transportation);

- systematically lead regulated tariffs for the population to economic levels and to determine the level of social support, based on cost- based tariffs.

- In the context of the integration of family policy and social protection should solve the issue of (Kochemyrovs"ka \& Pyshhulina, 2012):

- improving the standards of wages in Ukraine that will help create the foundation for economic self-sufficiency of families with children;

- creating conditions for successful combination of professional employment with parenthood (motherhood), in particular by expanding the network of childcare facilities and improve the quality of their services;

- ensuring the availability of quality health care for women and children;

- the introduction of tax incentives for families with children;

- development of special order opening deposit accounts for the accumulation of funds children from birth to adulthood;

- providing care for children whose parents have gone abroad for work (today (unofficial data) of about 200 children, but their records are not maintained, and they are socially vulnerable).

\section{CONCLUSIONS}

Thus, social security and social insurance system in Ukraine currently has many problems: unstable political situation and economic relations in society, the growing inflation, rising unemployment, the economic crisis of major sectors of the economy.

As a result, at the present stage of market reforms in Ukraine in the functioning of targeted social funds accumulated a number of unsolved problems of legislative and organizational:
- large contributions to the state social funds do not increase revenues from businesses, organizations, due to this phenomenon as "shadow" economy;

- lack of common principles defining the criteria necessary for social benefits;

- lack of clear direction in social spending to help families with low incomes;

- lack of consistency with other social costs of public expenditure;

- does not address the issue of forming a coordinated expenditure and the expenditure of public funds for social welfare payments through the use of state minimum social standards and so on.

In order to reach a new level, it is necessary to reform the social insurance system that provides for the introduction of five separate compulsory public insurance programs (pensions, health, due to temporary disability benefits, unemployment insurance, as well as the unfortunate accidents and occupational diseases). Separation of these types of social insurance will increase the effectiveness of protection against certain social risks.

To build a modern, sustainable, open and globally competitive economy, the formation of professional and effective governance, and finally - the welfare of citizens, Ukraine should implement the reform of social protection main tasks should be:

- an effective system of management of social risks;

- the harmonization of social policy employment policy, financial, economic and fiscal policy;

- reducing the negative impact of social risks in a way improving social security for families with children and strengthening targeted social support;

- review of social assistance to disabled and the most vulnerable members of society;

- reform of employment policy and social security, including pension;

- formation of socially oriented housing policy;

- eradication of poverty and the working population to bring quantitative and structural indicators subsistence level with the needs of social and economic development of Ukraine;

- healthcare reform; 
- restore public confidence in the direction of - to overcome the contradictions and social reform in government.

- create a functioning and for every able-bodied person the conditions that will allow it to maintain its prosperity through their own labor;

- social transformation towards improving the quality and accessibility of public services, setting standards and financial conditions of supply;

inconsistencies of the current legislation in order to reduce its volume, simplify maintenance, overcoming terminological confusion, getting rid of outdated regulations that are not justified, should be a codification of social legislation and develop social code based on the concept of social standardization.

\section{WORKS CITED}

Anon. (2010, 08 04). Zamozhne suspil"stvo, konkurentospromozhna ekonomika, efektyvna derzhava: Prohrama ekonomichnyx reform na 2010-2014 roky. Retrieved from Acting President of Ukraine - Official website: http://www.president.gov.ua/docs/Programa_reform_FINAL_1.pdf

Dokument 994_693. (2005, 02 12). Plan dij "Ukrayina - Yevropejs"kyj Soyuz". Retrieved from Verkhovna Rada Ukrayiny: http://zakon2.rada.gov.ua/laws/show/994_693/print131840314262796

Dokument v001p710-05. (2005, 03 17). Rishennya Konstytucijnoho Sudu Ukrayiny u spravi za konstytucijnym podannyam 47 narodnyx deputativ Ukrayiny shhodo vidpovidnosti Konstytuciyi Ukrayiny. Retrieved from Uakonodavstvo Ukrayiny: http://zakon2.rada.gov.ua/laws/show/v001p710-05

Haen, E. S. (2008, 06 10). Deklaracija MOT o social'noj spravedlivosti v celjah spravedlivoj globalizacii. Mezhdunarodnoja konferencija truda - sessija 97, (p. 28). Geneve. Retrieved from http://www.ilo.org/wcmsp5/groups/public/---dgreports/--cabinet/documents/genericdocument/wcms_100193.pdf

Honcharenko, V. (2002). Pravoznavstvo: Navchal"nyj posibnyk. / Za zahal"noyu redakciyeyu V.H. Honcharenka. Kyiv: Ukrayins"kyj informacijno-pravovyj centr.

Kochemyrovs"ka, O., \& Pyshhulina, O. (2012). Osnovni napryamy optymizaciyi systemy social"noho zaxystu v Ukrayini : Analitychna dopovid". Kyyiv: NISD - NACIONAL"'NYJ INSTYTUT STRATEHIChNYX DOSLIDZhEN"'."

Mel"nyk, K. (2003). Social"no-pravovyj zaxyst pracivnykiv orhaniv vnutrishnix sprav (problemy teoriyi ta praktyky): dys. ... kand. yuryd. nauk. NACIONAL"'NYJ UNIVERSYTET VNUTRIShNIX SPRAV.

Shajhatdinov, V. S. (1996). Pravo social'nogo obespechenija Rossijskoj Federacii : uchebn. posob. (1 ed.). Ekaterinburg.

Shajhatdinov, V. S. (1999). Sistema social'noj zashhity i obespechenija naselenija sovremennoj Rossii. Ekaterinburg.

Shul"ha, N. V. (2011). Spivvidnoshennya ponyat" «social"ne zabezpechennya» ta «social"nyj zahyst». Mytna sprava, 76(4), 24-28. Retrieved from http://www.nbuv.gov.ua/portal/soc_gum/ms/2011_4_2/24.pdf

Ukrayiny, V. R. (2009). Konstytuciya Ukrayiny: za stanom na 8.12.2004. Kyiv: Vydavnychyj dim "Skif".

Ustynov, S. (2011). Spivvidnoshennya terminiv "social"nyj zaxyst" ta "social"ne zabezpechennya" v zakonodavstvi Ukrayiny. Yurydychna nauka i praktyka, 90-95. Retrieved from http://nbuv.gov.ua/j-pdf/njj_2011_2_15.pdf

VI Doklad. (2011). Social'noe obespechenie $v$ celjah social'noj spravedlivosti i spravedlivoj globalizacii. Retrieved 05 08, 2014, from International Labour Organization: http://www.ilo.org/wcmsp5/groups/public/@ed_norm/@relconf/documents/meetingdocument/ wcms_154242.pdf 
Received for publication: $\quad 13.04 .2014$

Revision received: $\quad$ 04.05.2014

Accepted for publication: $\quad$ 18.06.2014

\section{How to cite this article?}

Style - APA Sixth Edition:

Byndyu, V. (2014). Problems and prospects of social protection in Ukraine. (Z. Čekerevac, Ed.) FBIM Transactions, 2(2), 15-23. doi:10.12709/fbim.02.02.02.02

Style - Chicago Fifteenth Edition:

Byndyu, Vita. 2014. "Problems and prospects of social protection in Ukraine." Edited by Zoran Čekerevac. FBIM Transactions 2 (2): 15-23. doi:10.12709/fbim.02.02.02.02.

Style - GOST Name Sort:

Byndyu Vita Problems and prospects of social protection in Ukraine [Journal] // FBIM Transactions / ed. Čekerevac Zoran. - Beograd : [s.n.], 2014. - 2 : Vol. 2. - pp. 15-23.

Style - Harvard Anglia:

Byndyu, V., 2014. Problems and prospects of social protection in Ukraine. FBIM Transactions, 2(2), pp. 15-23.

Style - ISO 690 Numerical Reference:

Problems and prospects of social protection in Ukraine. Byndyu, Vita. [ed.] Zoran Čekerevac. 2, Beograd : s.n., 2014, FBIM Transactions, Vol. 2, pp. 15-23. 